\title{
Schoolverlaters tussen onderwijs en arbeidsmarkt 2010. Feiten en cijfers
}

Citation for published version (APA):

Meng, C. M., \& van Thor, J. A. F. (2011). Schoolverlaters tussen onderwijs en arbeidsmarkt 2010. Feiten en cijfers. ROA. ROA Fact Sheets No. 003 https://doi.org/10.26481/umarof.2011003

Document status and date:

Published: 01/01/2011

DOI:

10.26481/umarof.2011003

Document Version:

Publisher's PDF, also known as Version of record

\section{Please check the document version of this publication:}

- A submitted manuscript is the version of the article upon submission and before peer-review. There can be important differences between the submitted version and the official published version of record.

People interested in the research are advised to contact the author for the final version of the publication, or visit the DOI to the publisher's website.

- The final author version and the galley proof are versions of the publication after peer review.

- The final published version features the final layout of the paper including the volume, issue and page numbers.

Link to publication

\footnotetext{
General rights rights.

- You may freely distribute the URL identifying the publication in the public portal. please follow below link for the End User Agreement:

www.umlib.nl/taverne-license

Take down policy

If you believe that this document breaches copyright please contact us at:

repository@maastrichtuniversity.nl

providing details and we will investigate your claim.
}

Copyright and moral rights for the publications made accessible in the public portal are retained by the authors and/or other copyright owners and it is a condition of accessing publications that users recognise and abide by the legal requirements associated with these

- Users may download and print one copy of any publication from the public portal for the purpose of private study or research.

- You may not further distribute the material or use it for any profit-making activity or commercial gain

If the publication is distributed under the terms of Article $25 \mathrm{fa}$ of the Dutch Copyright Act, indicated by the "Taverne" license above, 
U. Maastricht University in Learning!

Research Centre for Education and the Labour Market | ROA

\section{Schoolverlaters tussen onderwijs en arbeidsmarkt 2010 Feiten en cijfers}

\section{ROA Fact Sheet}

ROA-F-2011/3

Researchcentrum voor Onderwijs en Arbeidsmarkt | ROA Research Centre For Education and the Labour Market / ROA 


\section{Inleiding}

Het ROA verricht jaarlijks onderzoek onder schoolverlaters naar de overgang van school naar vervolgopleiding of arbeidsmarkt. Deze fact sheet presenteert de resultaten van de meting die eind 2010 is gehouden onder de afgestudeerden van het schooljaar 2008/2009, dat wil zeggen ongeveer anderhalf jaar na het voltooien van de opleiding. De resultaten hebben betrekking op nagenoeg de volle breedte van het onderwijs: VMBO, MBO-BOL, MBO-BBL, HAVO, VWO en HBO. Binnen het $\mathrm{MBO}$ wordt er nog onderscheid gemaakt tussen enerzijds de niveaus I en 2 , en anderzijds de niveaus 3 en 4 . In 20 Io heeft de VSNU geen meting onder universitair afgestudeerden gehouden. Er kunnen daardoor geen resultaten voor deze groep gepresenteerd worden. De data in het fact sheet zijn geaggregeerd, maar in de bijlage wordt ook nog een overzicht gegeven van de cijfers per opleidingsniveau gedifferentieerd naar studierichting. Voor de volledige resultaten met betrekking tot 2010 wordt verwezen naar het ROA-rapport Schoolverlaters tussen onderwijs en arbeidsmarkt 20I0. In totaal zijn 84.I00 gediplomeerde schoolverlaters en afgestudeerden benaderd. De totale respons bedroeg $31 \%$.

\section{Voorbereiding}

Tabel I laat zien in hoeverre men geslaagd is in het startbekwaam maken van leerlingen voor de arbeidsmarkt. Van de totale gediplomeerden uitstroom vindt $42 \%$ dat de gevolgde opleiding een goede basis biedt om te starten op de arbeidsmarkt. Dit percentage is het laagst bij gediplomeerden van VMBO, bijna 3 op Io gediplomeerde VMBO'ers (29\%) vindt de opleiding een goede basis voor de arbeidsmarktintrede, en het hoogst bij de hogere niveaus van BBL (6I\%). Voor BOL en in het bijzonder BBL geldt dat gediplomeerden van niveau 3 en 4 vaker vinden dat de gevolgde opleiding een goede basis biedt om te starten op de arbeidsmarkt dan studiegenoten van niveau I en 2 . In het $\mathrm{HBO}$ vindt iets meer dan de helft $(5 \mathrm{I} \%)$ de gevolgde opleiding een goede basis om te kunnen starten op de arbeidsmarkt. Wat betreft de afzonderlijke opleidingssectoren valt verder op dat gediplomeerden van gezondheidszorg op de hogere MBO-niveaus vaak van mening zijn dat de gevolgde opleiding een goede basis vormt om de arbeidsmarkt te betreden, terwijl gediplomeerden van BBL economie en in het bijzonder BOL economie deze mening juist niet delen.

In tabel I wordt tevens weergegeven welk deel van de gediplomeerden de gevolgde opleiding een goede basis vindt voor het verder ontwikkelen van kennis en vaardigheden gedurende de loopbaan. In tegenstelling tot de vraag in hoeverre de opleiding een goede basis vormt voor het starten op de arbeidsmarkt, de korte termijn doelstelling van het onderwijs, zeggen deze cijfers iets over de langere termijn doelstelling van het onderwijs. Van de totale groep gediplomeerden is 6 op de Io van mening dat de gevolgde opleiding een goede basis vormt voor de verdere ontwikkeling van kennis en vaardigheden. BBL'ers en HBO'ers zijn daarbij iets vaker dan gemiddeld tevreden over deze lange termijn doelstelling van het onderwijs. De gediplomeerden van de hogere BBL-niveaus zijn hier met $67 \%$ het vaakst tevreden over. Gediplomeerden uit de sector gezondheidszorg over bijna de hele breedte van het onderwijs zijn hier eveneens vaak tevreden over.

\section{Tabel 1}

Starten op arbeidsmarkt en verder ontwikkelen van kennis en vaardigheden

\begin{tabular}{|c|c|c|c|c|c|c|}
\hline & VMBO & $\begin{array}{l}\text { MBO- } \\
\text { BOL } \\
1 / 2\end{array}$ & $\begin{array}{l}\text { MBO- } \\
\text { BOL } \\
3 / 4\end{array}$ & $\begin{array}{c}M B 0- \\
B B L \\
1 / 2 \\
\end{array}$ & $\begin{array}{c}\text { MBO- } \\
\text { BBL } \\
3 / 4\end{array}$ & $\mathrm{HBO}$ \\
\hline $\begin{array}{l}\text { Opleiding biedt goede } \\
\text { basis om te starten op de } \\
\text { arbeidsmarkt (\%) }\end{array}$ & 29 & 41 & 44 & 46 & 61 & 51 \\
\hline $\begin{array}{l}\text { Opleiding biedt goede } \\
\text { basis voor het verder } \\
\text { ontwikkelen van kennis } \\
\text { en vaardigheden (\%) }\end{array}$ & 58 & 59 & 58 & 62 & 67 & 65 \\
\hline
\end{tabular}

Bron: ROA (SIS)

\section{Vervolgonderwijs}

$\mathrm{Na}$ het afronden van de studie kunnen schoolverlaters er voor kiezen om de arbeidsmarkt te betreden of om verder te leren. In figuur I staat een overzicht van de kwalificerende vervolgtrajecten van de gediplomeerde schoolverlaters uit het onderzoek. De figuur vermeldt per onderwijssoort het percentage van de gediplomeerde schoolverlaters dat sinds het moment van afstuderen naar een bepaald kwalificerend vervolgtraject is gegaan evenals het percentage dat niet voor een kwalificerend vervolgtraject heeft gekozen. Voor de duidelijkheid zijn in de figuur de BOL- en BBL-niveaus samengevoegd en worden alleen vervolgtrajecten met een aandeel van ten minste $5 \%$ weergegeven.

Van het AVO stroomt het overgrote deel door naar een vervolgopleiding. Van de totale groep HAVO-respondenten is $79 \%$ doorgestroomd naar een $\mathrm{HBO}$-opleiding. Van de VWO'ers is $\mathrm{I} 4 \%$ naar het $\mathrm{HBO}$ gegaan en heeft het merendeel, $73 \%$, voor een studie in het WO gekozen. Van de gediplomeerde VMBO-respondenten kiest minder dan $5 \%$ niet voor een vervolgopleiding. Deze groep verlaat het onderwijs dus zonder startkwalificatie. Dit wil overigens niet zeggen dat deze schoolverlaters definitief verloren zijn voor het onderwijs, ze zijn alleen niet direct na het behalen van hun VMBO-diploma doorgestroomd naar een vervolgstudie. De doorstroom van VMBO naar HAVO is volgens de figuur kleiner dan $5 \%$. Hier is mogelijk sprake van een lichte onderschatting, omdat scholieren die binnen dezelfde middelbare school van VMBO naar HAVO doorstromen iets minder zouden kunnen responderen dan degenen die naar een andere instelling gaan. 
Figuur 1

Kwalificerende vervolgtrajecten na het verlaten van de opleiding

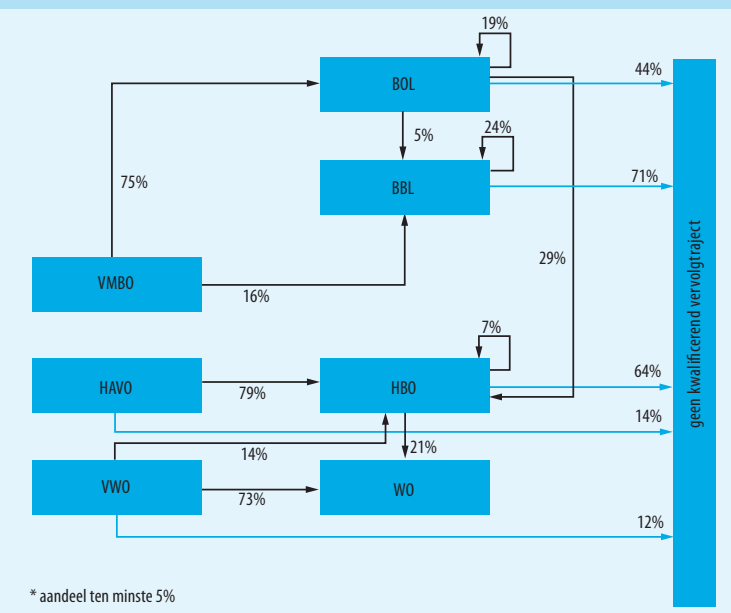

Bron: ROA (SIS)

Aan de schoolverlaters die doorstromen naar een vervolgopleiding is gevraagd hoe zij de aansluiting beoordelen tussen de voltooide opleiding en de vervolgopleiding. Figuur 2 geeft weer welk deel van de verder lerende schoolverlaters deze aansluiting voldoende of goed vindt. Aangezien de doorstroom vanuit het hoger onderwijs naar regulier vervolgonderwijs gering is en het feit dat het hoger onderwijs niet primair gericht is op vervolgonderwijs, is de betreffende vraag niet voorgelegd aan $\mathrm{HBO}$-afgestudeerden. De overgrote meerderheid van de doorstromers naar een vervolgopleiding is van mening dat de aansluiting tussen de eerder gevolgde opleiding en de vervolgopleiding voldoende tot goed is. Bij zowel BOL als BBL valt op dat het oordeel over een goede aansluiting afneemt naarmate het gevolgde onderwijsniveau toeneemt. Voor beide leerwegen geldt dat van de doorstromers van de hogere niveaus 'slechts' $65 \%$ de aansluiting als voldoende of goed beoordeelt. Dit betekent natuurlijk tegelijkertijd dat ruim I op de 3 de aansluiting matig of slecht vindt. Verder blijkt dat gediplomeerden uit de gezondheidszorg behoorlijk tevreden zijn over de aansluiting. Vooral gediplomeerden van niveau I en 2 binnen BBL zijn tevreden over de aansluiting (92\%).

Figuur 2

Percentage dat de aansluiting tussen de gevolgde opleiding en de vervolgopleiding voldoende of goed vindt

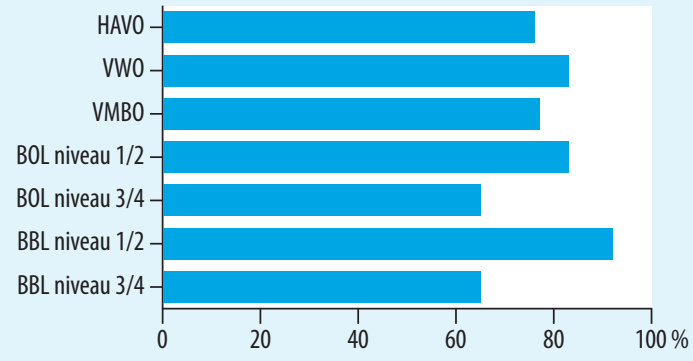

Bron: ROA (SIS)

Naast het totale aandeel jongeren dat de vervolgopleiding voortijdig verlaat, laat figuur 3 zien welk deel van hen de vervolgopleiding op het enquêtemoment heeft verlaten zonder aan een nieuwe studie begonnen te zijn (de netto uitvallers) en welk deel van vervolgopleiding gewisseld is. In totaal geeft $\mathrm{II} \%$ van de verder lerende schoolverlaters op het enquêtemoment aan gestopt te zijn met de aanvankelijk gekozen vervolgopleiding. Van alle onderwijsniveaus zijn het de Havisten en VWO'ers die het vaakst voortijdig stoppen met de vervolgopleiding (respectievelijk I6\% en I4\%). Schoolverlaters van niveau I en 2 binnen BBL ( $5 \%$ ) stoppen daarentegen het minst voortijdig met de vervolgopleiding. Voor beide leerwegen binnen het $\mathrm{MBO}$ geldt bovendien dat schoolverlaters van niveau 3 en 4 vaker voortijdig met de vervolgopleiding stoppen dan studiegenoten van niveau I en 2. Doorstromers van het $\mathrm{HBO}$ doen het beter dan gemiddeld; van deze groep stopt $7 \%$ voortijdig met de vervolgopleiding.

\section{Figuur 3}

Percentage dat de vervolgopleiding voortijdig heeft verlaten (netto uitval) en het percentage studiewisselaars

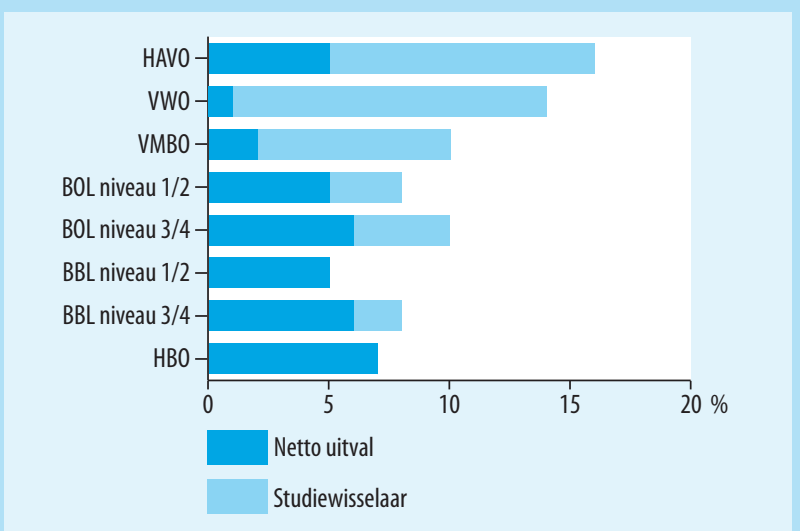

Bron: ROA (SIS)

Het percentage 'afhakers' vlak na aanvang van de vervolgstudie is in werkelijkheid echter minder problematisch dan het op het eerste gezicht lijkt. Wellicht nog belangrijker dan de totale groep 'afhakers', is het percentage van hen dat ook niet meer aan een andere studie begint. Met andere woorden is de netto uitval nog interessanter dan de bruto uitval. Daarom rijst de vraag: welk deel van de uitvallers zijn studiewisselaars en welk deel heeft daadwerkelijk het onderwijs verlaten? Van de II\% doorstromers die voortijdig gestopt zijn met de vervolgopleiding is $7 \%$-punt van studie gewisseld. Deze jongeren blijven dus voor het onderwijs behouden, maar lijken in eerste instantie een verkeerde studiekeuze te hebben gemaakt. De overige $4 \%$-punt bestaat uit netto uitvallers. Het relatief grote percentage uitvallers onder Havisten ( $16 \%$ ) blijkt voor het grootste deel te bestaan uit studiewisselaars (II\%-punt). Ook het percentage studiewisselaars onder gestopte VWO'ers is hoog ( $13 \%$ punt). Wanneer de resultaten gedifferentieerd worden naar opleidingssector blijkt de netto uitval vooral hoog te zijn bij enkele sectoren op het hoogste MBO-niveau. Op BOL niveau 4 bedraagt het percentage netto uitvallers onder jongeren uit de sector gedrag en maatschappij die voortijdig gestopt zijn met een vervolgopleiding bijvoorbeeld

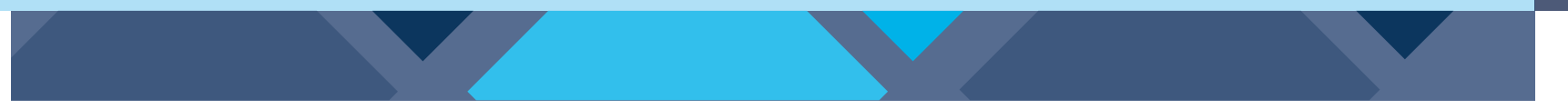


9\%-punt. Onder doorstromers van het $\mathrm{HBO}$ is de netto uitval het laagst bij gezondheidszorg (4\%-punt) en het hoogst bij taal en cultuur (II\%-punt).

\section{Arbeidsmarkt}

In plaats van te kiezen voor een vervolgopleiding kunnen gediplomeerden er natuurlijk eveneens voor kiezen om een baan te zoeken en zich aan te bieden op de arbeidsmarkt. Er zijn verschillende indicatoren die aangeven hoe soepel de overgang tussen onderwijs en arbeidsmarkt verloopt voor schoolverlaters. Allereerst kan er bijvoorbeeld gekeken worden naar het werkloosheidsniveau onder schoolverlaters die zich aanbieden op de arbeidsmarkt (figuur 4). De totale werkloosheid onder schoolverlaters op het moment van enquêteren bedraagt $6,5 \%$. De gevolgen van de economische crisis blijken vooral uit de hoge werkloosheid onder laagopgeleiden. Onder VMBO'ers is de werkloosheid $8 \%$. De werkloosheid onder BOL-gediplomeerden verschilt aanzienlijk tussen de lagere en hogere niveaus. Van de schoolverlaters van niveau I en 2 is maar liefst $16 \%$ werkloos, terwijl dit voor schoolverlaters van niveau 3 en $46 \%$ is. Op BBL-niveau is er minder werkloosheid en bovendien verschillen de werkloosheidspercentages tussen schoolverlaters van de lagere $(5 \%)$ en hogere (2\%) BBL-niveaus niet zoveel van elkaar. Het werkloosheidspercentage onder afgestudeerden van het $\mathrm{HBO}$ bedraagt 6\%. Daarnaast blijkt uit de data dat gediplomeerden van de economische sector over de hele breedte van het onderwijs relatief vaak werkloos zijn.

Het werkloosheidspercentage op het enquêtemoment zegt echter niet alles over hoe soepel de intrede op de arbeidsmarkt verlopen is. In dezelfde figuur staan daarom cijfers met betrekking tot de zoekduur naar de eerste baan. De figuur geeft weer welk deel van de schoolverlaters 4 maanden of langer werkloos is geweest voordat de eerste baan gevonden werd. Van alle gediplomeerde schoolverlaters die instromen op de arbeidsmarkt heeft 7\% 4 maanden of langer moeten zoeken naar de eerste baan. Gediplomeerden van niveau I en 2 binnen $\mathrm{BOL}$ en van $\mathrm{HBO}$ (beide $13 \%$ ) zoeken doorgaans het vaakst vier maanden of langer alvorens hun eerste baan te vinden. Voor laatstgenoemde groep ligt dit ook voor de hand omdat hoger opgeleiden er meer baat bij hebben om wat langer te zoeken naar een geschikte baan. Uitzonderingen hierop vormen gediplomeerden van $\mathrm{HBO}$ economie en $\mathrm{HBO}$ onderwijs. $\mathrm{Zij}$ vinden relatief vaak al binnen 4 maanden hun eerste baan. BBL'ers hebben het minst lang nodig bij de zoektocht naar hun eerste baan. Van de lagere en hogere BBL-niveaus zoekt respectievelijk $5 \%$ en $2 \%$ vier maanden of langer alvorens de eerste baan te vinden. Bovendien geldt voor zowel de gediplomeerde BOL-uitstroom als de gediplomeerde BBL-uitstroom dat naarmate het niveau van de voltooide opleiding lager is, er langer gezocht moet worden voordat de eerste baan gevonden wordt.
Figuur 4

Werkloosheid onder gediplomeerde schoolverlaters

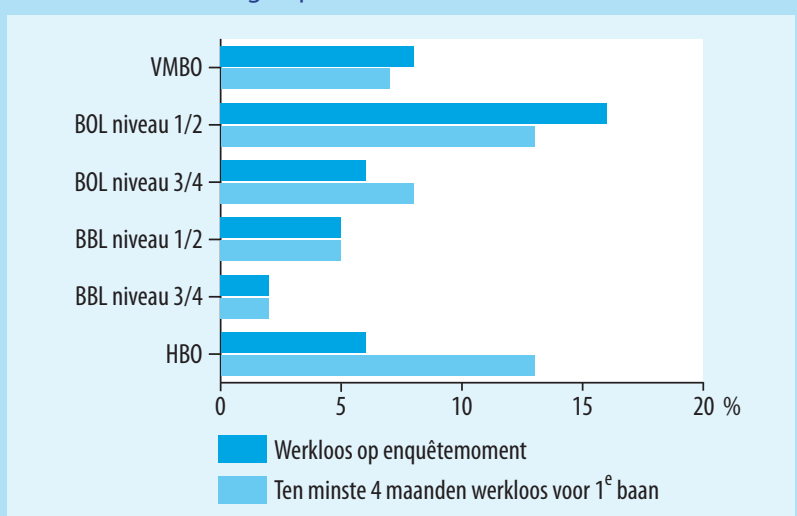

Bron: ROA (SIS)

Tevens is gekeken naar de ontwikkeling van het werkloosheidspercentage van schoolverlaters gedurende de periode 2000-20I0. In figuur 5 wordt deze ontwikkeling voor de verschillende opleidingsniveaus weergegeven. Nadat de werkloosheid rond 2004 erg hoog was, zien we een daling tot het moment dat de crisis uitbrak. Hierdoor steeg de werkloosheid licht. In 2010 verschilt de werkloosheidsontwikkeling per opleidingsniveau. In vergelijking met 2009 bleef het werkloosheidniveau in 2010 bijvoorbeeld vrijwel constant op BOL niveau $\mathrm{I} / 2$ en $\mathrm{HBO}$, terwijl de werkloosheid op BOL niveau $3 / 4$ met $2 \%$ afnam, en de werkloosheid op VMBO-niveau juist met $2 \%$ toenam.

Figuur 5

Trendcijfers werkloosheid naar opleidingsniveau, 2000-2010

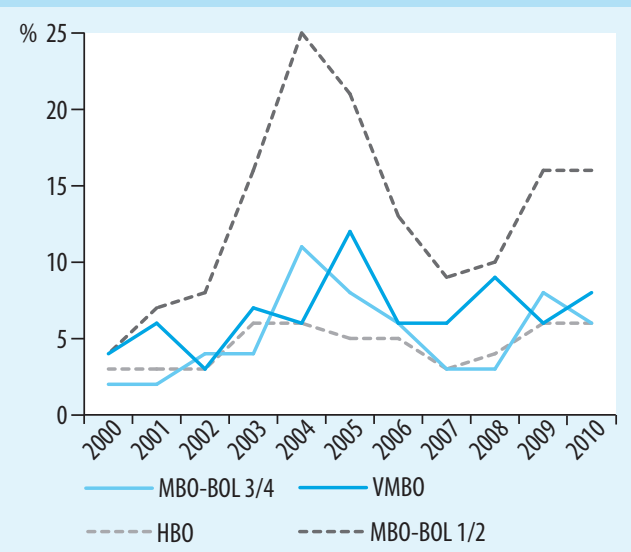

Bron: ROA (SIS)

Opmerking: In de metingen van $2000 \mathrm{t} / \mathrm{m} 2002$ betreft het schoolverlaters van MAVO/VBO. Vanaf de meting 2003 betreft het schoolverlaters van VMBO.

In figuur 6 worden de werkloosheidspercentages van schoolverlaters per provincie weergegeven. Het gaat hierbij om de provincie waar de schoolverlaters op het enquêtemoment wonen. Schoolverlaters uit Flevoland zijn het vaakst werkloos (bijna I4\%), gevolgd door schoolverlaters uit de Noordelijke provincies Groningen en Friesland. In deze beide provincies is I op de Io gediplomeerden werkloos op het enquêtemoment. Wat betreft het werkloosheidspercentage kunnen schoolverlaters in 2010 het beste wonen in 
Overijssel of Zeeland. Het werkloosheidspercentage onder schoolverlaters bedraagt in deze provincies minder dan $4 \%$.

Figuur 6

Werkloosheidspercentage per provincie

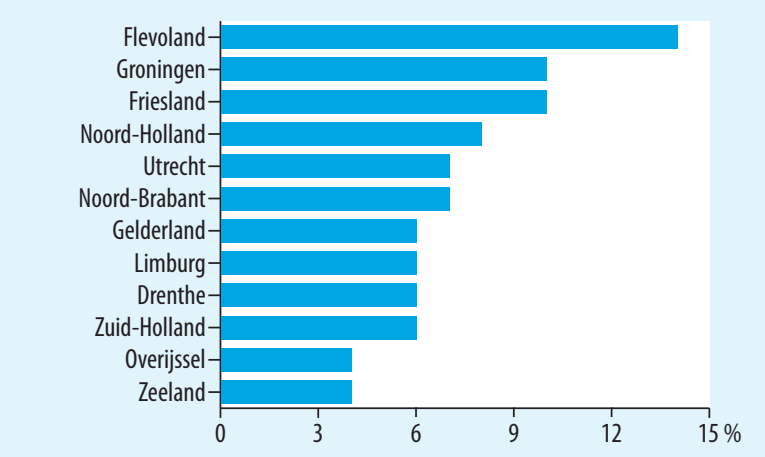

Bron: ROA (SIS)

Naast werkloosheidscijfers zijn er nog enkele andere belangrijke indicatoren die een beeld geven van de aansluiting tussen onderwijs en arbeidsmarkt. Figuur 7 laat zien hoe goed de baan van schoolverlaters aansluit bij hun afgeronde opleiding wat betreft niveau en richting. Van alle werkende schoolverlaters heeft gemiddeld zo'n driekwart een baan op minimaal het eigen opleidingsniveau. Van de werkende VMBO-uitstroom geeft ruim 9 op de Io aan een baan op minimaal het eigen opleidingsniveau te hebben. Dit kan verklaard worden door het feit dat er weinig banen zijn waarvoor het vereiste opleidingsniveau lager is dan VMBO. Ook gediplomeerde schoolverlaters van de hogere BOL-niveaus $(84 \%)$ vinden relatief vaak een baan op ten minste het eigen niveau. Voor zowel BOL als BBL geldt dat schoolverlaters van niveau I en 2 minder vaak werk op het eigen niveau hebben dan hun studiegenoten van niveau 3 en 4. Bovendien blijken 8 op de Io HBO-afgestudeerden een functie op minimaal het eigen niveau te hebben $(79 \%)$. Werkzame schoolverlaters met een diploma $\mathrm{HBO}$ onderwijs hebben erg vaak een baan op minimaal hun eigen niveau, terwijl degenen met een diploma HBO gedrag en maatschappij juist vaak onder hun niveau werken. Op MBO-niveau werken gediplomeerden uit de sectoren gezondheidszorg en gedrag en maatschappij relatief vaak op ten minste het eigen niveau.

Naast het niveau van de functie is ook de richting van de functie van belang om iets te kunnen zeggen over de kwaliteit van de baan. In de vragenlijst is daarom gevraagd om aan te geven wat volgens de werkgever de vereiste opleidingsrichting is. De vereiste opleidingsrichting zegt iets over de mate waarin iemand werkzaamheden verricht die binnen het beroependomein vallen waarvoor hij of zij is opgeleid. Uit figuur 7 blijkt dat schoolverlaters van het $\mathrm{VMBO}$ en niveau $\mathrm{I}$ en 2 binnen BOL en BBL het minst werkzaam zijn binnen het eigen beroependomein. Van deze werkzame schoolverlaters werkt iets meer dan $60 \%$ in de eigen of een verwante richting. Bij de hogere niveaus van het $\mathrm{MBO}$ werkt
$76 \%$ van de BOL'ers in het eigen beroependomein, terwijl dit bij de BBL'ers zelfs $8 \mathrm{I} \%$ is. Van de HBO'ers werkt $79 \%$ in de eigen richting of in een verwante richting. Verder valt nog op dat middelbaar- en hoogopgeleide schoolverlaters met een opleiding richting gezondheidszorg of gedrag en maatschappij vaak een baan vinden die gerelateerd is aan hun opleiding. Van alle opleidingen zijn het degenen met een diploma $\mathrm{HBO}$ onderwijs die het vaakst in het eigen beroependomein werkzaam zijn (95\%).

Figuur 7

Percentage met een baan op minimaal eigen niveau en percentage met een baan in eigen/verwante richting

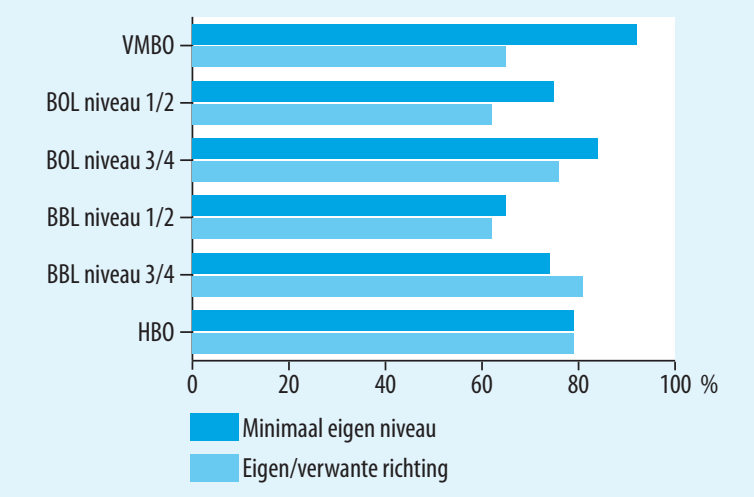

Bron: ROA (SIS)

Figuur 8

Percentage dat de aansluiting tussen opleiding en werk als goed of voldoende beoordeelt

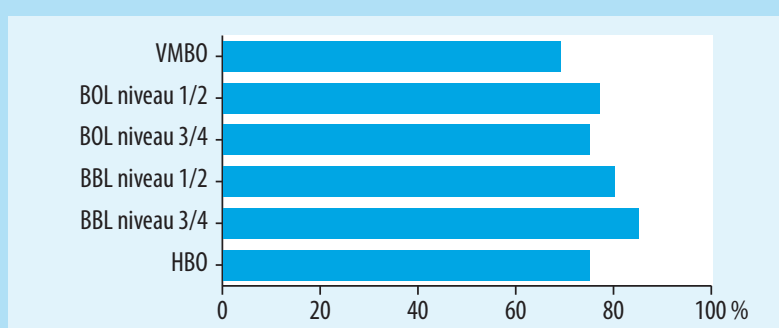

Bron: ROA (SIS)

De geënquêteerden is eveneens gevraagd wat zij vinden van de aansluiting tussen de gevolgde opleiding en de huidige functie. Figuur 8 geeft weer welk deel van de werkzame schoolverlaters de aansluiting voldoende of goed vindt. BBL-gediplomeerden van de hogere en lagere niveaus zijn met respectievelijk $85 \%$ en $80 \%$ het vaakst tevreden over de aansluiting. Een mogelijke verklaring hiervoor is de sterkere relatie tussen opleiding en arbeidsmarkt in de BBL. In het $\mathrm{HBO}$ is driekwart van de werkende afgestudeerden van mening dat de aansluiting tussen opleiding en werk voldoende of goed is. Hoewel werkende VMBO'ers van alle opleidingsniveaus het minst tevreden over de aansluiting blijken te zijn, vindt van deze groep nog altijd bijna 7 op de Io werkenden dat de aansluiting tussen opleiding en huidige functie voldoende of goed is. Over de hele linie zijn schoolverlaters uit de gezondheidszorg behoorlijk tevreden over de aansluiting tussen opleiding en werk. Op HBO-niveau 
blijken degenen die een lerarenopleiding gevolgd hebben eveneens erg tevreden over de aansluiting.

Een andere indicator voor de kwaliteit van het werk en de transitie tussen onderwijs en arbeidsmarkt is de beloning die werkzame schoolverlaters ontvangen. In tabel 2 wordt per opleidingsniveau het gemiddelde bruto uurloon weergegeven. Het uurloon biedt een eerlijkere vergelijking dan het maandloon, omdat verschillen in het maandloon ook veroorzaakt kunnen worden door het aantal gewerkte uren. Het gemiddeld bruto uurloon neemt zoals verwacht toe met het opleidingsniveau. Het gemiddeld bruto uurloon van werkende VMBO-schoolverlaters is $€ 4,68$, hetgeen iets lager is dan een jaar eerder $(€ 4,83)$. Bij de overige opleidingsniveaus is het gemiddelde uurloon wel enigszins gestegen ten opzichte van 2009. Zowel voor BOL als BBL is het uurloon hoger naarmate het niveau van het diploma hoger is. Bij de BOL-uitstroom loopt dit op van gemiddeld $€ 7,69$ voor de lagere niveaus tot $€$ I0,37 voor de hogere niveaus en bij de BBL-uitstroom varieert dit van $€$ IO,I2 tot $€ \mathrm{I} 2,59$. BBL-schoolverlaters verdienen gemiddeld genomen dus meer dan hun studiegenoten van BOL, wat deels verklaard kan worden uit het feit dat werkende BBL'ers gemiddeld zo'n 7,5 jaar ouder zijn dan werkende BOL'ers en vaak al iets meer werkervaring hebben opgebouwd. Het gemiddeld bruto uurloon onder afgestudeerde HBO'ers is $€ 13,53$.

Tabel 2

Gemiddeld bruto uurloon

\begin{tabular}{lcccccc}
\hline & VMBO & $\begin{array}{c}\text { MBO- } \\
\text { BOL 1/2 }\end{array}$ & $\begin{array}{c}\text { MBO- } \\
\text { BOL 3/4 }\end{array}$ & $\begin{array}{c}\text { MBO- } \\
\text { BBL 1/2 }\end{array}$ & $\begin{array}{c}\text { MBO- } \\
\text { BBL 3/4 }\end{array}$ & HBO \\
\hline Bruto uurloon (euro) & 4,68 & 7,69 & 10,37 & 10,12 & 12,59 & 13,53 \\
\hline
\end{tabular}

Bron: ROA (SIS)

Bij de afzonderlijke opleidingssectoren valt het op dat afgestudeerden van gezondheidszorg gemiddeld een relatief hoog bruto uurloon hebben. Omdat zij echter vaker in deeltijd werken dan andere afgestudeerden betekent dit niet automatisch dat zij ook een hoog bruto maandloon hebben.

\section{Tevredenheid met opleiding achteraf}

In figuur 9 wordt het percentage gediplomeerde schoolverlaters weergegeven dat de afgeronde opleiding, achteraf bezien, opnieuw zou volgen. Hierbij gaat het alleen om schoolverlaters van het $\mathrm{MBO}$ en $\mathrm{HBO}$. De overgrote meerderheid van de gediplomeerde schoolverlaters zou achteraf bezien opnieuw kiezen voor de gevolgde opleiding. De BBL-gediplomeerden van de hogere niveaus ( $85 \%$ ) zouden het vaakst opnieuw voor de gevolgde opleiding kiezen. Maar ook van de gediplomeerden van BOL niveau $\mathrm{I} / 2$, die achteraf het minst nogmaals voor dezelfde opleiding zouden kiezen, zegt nog altijd 3 op de 4 voor dezelfde opleiding te zouden kiezen. Gediplomeerden van de hogere BOL-niveaus, de lagere BBL-niveaus alsook $\mathrm{HBO}$, geven in 8 van de Io gevallen aan opnieuw voor de gevolgde opleiding te zullen kiezen als zij nog eens opnieuw zouden mogen kiezen.

\section{Figuur 9}

Gevolgde opleiding opnieuw kiezen

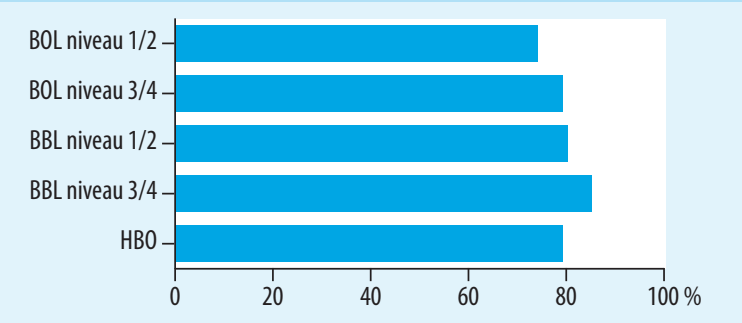

Bron: ROA (SIS) 


\section{Algemeen}

\begin{tabular}{|c|c|c|c|}
\hline & $\begin{array}{l}\text { Opleiding goede basis om te starten op } \\
\text { arbeidsmarkt (\%) }\end{array}$ & $\begin{array}{l}\text { Opleiding goede basis voor verder } \\
\text { ontwikkelen van kennis en vaardigheden (\%) }\end{array}$ & $\begin{array}{l}\text { Opleiding achteraf } \\
\text { opnieuw kiezen \% }\end{array}$ \\
\hline VMB0 theoretische leerweg & 25 & 62 & 89 \\
\hline VMBO landbouw & 23 & 48 & 83 \\
\hline VMBO techniek & 34 & 54 & 82 \\
\hline VMB0 economie & 31 & 59 & 76 \\
\hline VMBO gezondheidszorg & 33 & 60 & 82 \\
\hline BOL 1 & 35 & 58 & 72 \\
\hline BOL 2 landbouw & 42 & 55 & 72 \\
\hline BOL 2 techniek & 47 & 55 & 64 \\
\hline BOL 2 economie & 40 & 60 & 76 \\
\hline BOL 2 gezondheidszorg & 44 & 62 & 81 \\
\hline BOL 3 landbouw & 35 & 43 & 73 \\
\hline BOL 3 techniek & 50 & 64 & 92 \\
\hline BOL 3 economie & 38 & 54 & 73 \\
\hline BOL 3 gezondheidszorg & 56 & 69 & 78 \\
\hline BOL 3 gedrag en maatschappij & 56 & 64 & 85 \\
\hline BOL 4 landbouw & 34 & 47 & 75 \\
\hline BOL 4 techniek & 42 & 55 & 79 \\
\hline BOL 4 economie & 33 & 52 & 76 \\
\hline BOL 4 gezondheidszorg & 58 & 65 & 81 \\
\hline BOL 4 gedrag en maatschappij & 42 & 58 & 81 \\
\hline BBL 1 & 34 & 64 & 75 \\
\hline BBL 2 landbouw & 41 & 54 & 82 \\
\hline BBL 2 techniek & 50 & 64 & 81 \\
\hline BBL 2 economie & 47 & 54 & 78 \\
\hline BBL 2 gezondheidszorg & 49 & 69 & 84 \\
\hline BBL 3 landbouw & 46 & 50 & 90 \\
\hline BBL 3 techniek & 60 & 68 & 84 \\
\hline BBL 3 economie & 40 & 52 & 78 \\
\hline BBL 3 gezondheidszorg & 76 & 83 & 95 \\
\hline BBL 3 gedrag en maatschappij & 65 & 67 & 77 \\
\hline BBL 4 landbouw & 45 & 74 & 93 \\
\hline BBL 4 techniek & 66 & 75 & 87 \\
\hline BBL 4 economie & 47 & 47 & 69 \\
\hline BBL 4 gezondheidszorg & 72 & 74 & 78 \\
\hline BBL 4 gedrag en maatschappij & 68 & 69 & 94 \\
\hline HBO landbouw & 52 & 66 & 78 \\
\hline HBO techniek & 60 & 69 & 84 \\
\hline HBO economie & 46 & 63 & 72 \\
\hline HB0 gezondheidszorg & 63 & 70 & 85 \\
\hline HBO gedrag en maatschappij & 46 & 63 & 75 \\
\hline $\mathrm{HBO}$ onderwijs & 62 & 62 & 87 \\
\hline HBO taal en cultuur & 32 & 72 & 87 \\
\hline
\end{tabular}

Bron: ROA (SIS) 


\section{Vervolgopleiding}

\begin{tabular}{|c|c|c|c|}
\hline & $\begin{array}{l}\text { Aansluiting } \\
\text { redelijk/goed \% }\end{array}$ & $\begin{array}{l}\text { Netto uitval } \\
\text { in vervolgopleiding \% }\end{array}$ & $\begin{array}{c}\text { Studiewisselaar } \\
\text { in vervolgopleiding \% }\end{array}$ \\
\hline HAVO & 76 & 5 & 11 \\
\hline VW0 & 83 & 1 & 13 \\
\hline VMBO theoretische leerweg & 76 & 2 & 9 \\
\hline VMBO landbouw & 72 & 3 & 10 \\
\hline VMBO techniek & 80 & 3 & 3 \\
\hline VMBO economie & 81 & 3 & 6 \\
\hline VMBO gezondheidszorg & 76 & 2 & 11 \\
\hline BOL 1 & 94 & 6 & 5 \\
\hline BOL 2 landbouw & 68 & 7 & 0 \\
\hline BOL 2 techniek & 81 & 7 & 0 \\
\hline BOL 2 economie & 84 & 2 & 3 \\
\hline BOL 2 gezondheidszorg & 82 & 4 & 3 \\
\hline BOL 3 landbouw & 67 & 8 & 1 \\
\hline BOL 3 economie & 68 & 4 & 3 \\
\hline BOL 3 gezondheidszorg & 72 & 4 & 1 \\
\hline BOL 3 gedrag en maatschappij & 81 & 5 & 1 \\
\hline BOL 4 landbouw & 60 & 8 & 4 \\
\hline BOL 4 techniek & 57 & 5 & 6 \\
\hline BOL 4 economie & 67 & 6 & 5 \\
\hline BOL 4 gezondheidszorg & 65 & 7 & 0 \\
\hline BOL 4 gedrag en maatschappij & 64 & 9 & 5 \\
\hline BBL 1 & 82 & 7 & 0 \\
\hline BBL 2 & 91 & 5 & 0 \\
\hline BBL 3 & 81 & 4 & 1 \\
\hline BBL 4 & 71 & 11 & 2 \\
\hline HBO landbouw & $x$ & 5 & 0 \\
\hline HBO techniek & $x$ & 7 & 1 \\
\hline HBO economie & $x$ & 7 & 0 \\
\hline HBO gezondheidszorg & $x$ & 4 & 0 \\
\hline HBO gedrag en maatschappij & $x$ & 8 & 0 \\
\hline HBO onderwijs & $x$ & 7 & 0 \\
\hline HBO taal en cultuur & $x$ & 11 & 0 \\
\hline
\end{tabular}

Bron: ROA (SIS) 


\section{Arbeidsmarkt}

\begin{tabular}{|c|c|c|c|c|c|c|}
\hline & $\begin{array}{c}\text { Minimaal op eigen } \\
\text { niveau } \%\end{array}$ & $\begin{array}{c}\text { Eigen/verwante } \\
\text { richting } \%\end{array}$ & $\begin{array}{c}\text { Aansluiting } \\
\text { voldoende/goed \% }\end{array}$ & Werkloos \% & $\begin{array}{l}\text { Intrede werkloosheid } \\
\qquad>3 \mathrm{mnd} \%\end{array}$ & $\begin{array}{l}\text { Bruto uurloon } \\
\quad \text { euro }\end{array}$ \\
\hline VMBO theoretische leerweg & 87 & 53 & 57 & 17 & 8 & 4,63 \\
\hline VMBO landbouw & 92 & 72 & 76 & 8 & 2 & 4,50 \\
\hline VMBO techniek & 95 & 75 & 69 & 3 & 3 & 5,15 \\
\hline VMBO economie & 89 & 62 & 67 & 11 & 4 & 3,91 \\
\hline VMB0 gezondheidszorg & 90 & 50 & 81 & 5 & 9 & 4,32 \\
\hline BOL 1 & 79 & 77 & 82 & 25 & 6 & 5,96 \\
\hline BOL 2 landbouw & 82 & 50 & 74 & 12 & 8 & 9,02 \\
\hline BOL 2 techniek & 86 & 59 & 74 & 17 & 7 & 8,63 \\
\hline BOL 2 economie & 62 & 47 & 73 & 13 & 9 & 7,54 \\
\hline BOL 2 gezondheidszorg & 81 & 79 & 85 & 14 & 9 & 8,19 \\
\hline BOL 3 landbouw & 73 & 56 & 71 & 4 & 3 & 7,57 \\
\hline BOL 3 techniek & 53 & 70 & 62 & 7 & 3 & 10,57 \\
\hline BOL 3 economie & 68 & 65 & 63 & 10 & 7 & 8,44 \\
\hline BOL 3 gezondheidszorg & 76 & 81 & 87 & 1 & 4 & 10,09 \\
\hline BOL 3 gedrag en maatschappij & 94 & 90 & 85 & 5 & 4 & 10,59 \\
\hline BOL 4 landbouw & 76 & 67 & 76 & 9 & 5 & 9,45 \\
\hline BOL 4 techniek & 82 & 70 & 71 & 8 & 8 & 10,94 \\
\hline BOL 4 economie & 81 & 65 & 77 & 8 & 9 & 9,25 \\
\hline BOL 4 gezondheidszorg & 95 & 87 & 73 & 1 & 5 & 11,63 \\
\hline BOL 4 gedrag en maatschappij & 92 & 83 & 74 & 6 & 7 & 11,16 \\
\hline BBL 1 & 44 & 51 & 81 & 7 & 0 & 9,10 \\
\hline BBL 2 landbouw & 59 & 53 & 83 & 0 & 3 & 9,47 \\
\hline BBL 2 techniek & 69 & 66 & 74 & 4 & 3 & 9,97 \\
\hline BBL 2 economie & 67 & 54 & 81 & 7 & 2 & 9,96 \\
\hline BBL 2 gezondheidszorg & 74 & 79 & 92 & 6 & 5 & 12,35 \\
\hline BBL 3 landbouw & 61 & 84 & 65 & 1 & 0 & 10,79 \\
\hline BBL 3 techniek & 55 & 79 & 88 & 0 & 2 & 13,03 \\
\hline BBL 3 economie & 59 & 62 & 75 & 6 & 0 & 9,34 \\
\hline BBL 3 gezondheidszorg & 84 & 88 & 96 & 1 & 0 & 12,65 \\
\hline BBL 3 gedrag en maatschappij & 93 & 87 & 91 & 0 & 2 & 11,43 \\
\hline BBL 4 techniek & 74 & 81 & 77 & 0 & 0 & 14,48 \\
\hline BBL 4 economie & 73 & 65 & 73 & 6 & 0 & 10,66 \\
\hline BBL 4 gezondheidszorg & 93 & 90 & 87 & 1 & 2 & 14,54 \\
\hline BBL 4 gedrag en maatschappij & 91 & 88 & 90 & 2 & 0 & 14,21 \\
\hline HBO landbouw & 76 & 72 & 75 & 6 & 13 & 13,72 \\
\hline HBO techniek & 85 & 86 & 77 & 5 & 13 & 14,15 \\
\hline $\mathrm{HBO}$ economie & 77 & 66 & 69 & 8 & 16 & 13,33 \\
\hline HBO gezondheidszorg & 82 & 93 & 81 & 3 & 7 & 15,06 \\
\hline HBO gedrag en maatschappij & 62 & 87 & 71 & 7 & 14 & 13,62 \\
\hline $\mathrm{HBO}$ onderwijs & 94 & 95 & 87 & 5 & 5 & 13,89 \\
\hline HBO taal en cultuur & 77 & 68 & 73 & 6 & 13 & 9,52 \\
\hline
\end{tabular}




\section{Trendcijfers werkeloosheid}

\begin{tabular}{|c|c|c|c|c|c|c|c|c|c|c|c|}
\hline & 2000 & 2001 & 2002 & 2003 & 2004 & 2005 & 2006 & 2007 & 2008 & 2009 & 2010 \\
\hline HAVO & - & 2 & 8 & 17 & 18 & 19 & 11 & 17 & 17 & 19 & 15 \\
\hline vwo & - & 6 & 4 & 13 & 15 & 19 & 5 & 23 & 11 & 12 & 18 \\
\hline VMBO & 4 & 6 & 3 & 7 & 6 & 12 & 6 & 6 & 9 & 6 & 8 \\
\hline MBO-BOL 1/2 & 4 & 7 & 8 & 16 & 25 & 21 & 13 & 9 & 10 & 16 & 16 \\
\hline MBO-BOL $3 / 4$ & 2 & 2 & 4 & 4 & 11 & 8 & 6 & 3 & 3 & 8 & 6 \\
\hline MBO-BBL 1/2 & - & - & - & - & - & - & - & 3 & 1 & 4 & 5 \\
\hline MBO-BBL 3/4 & - & - & - & - & - & - & - & 1 & 1 & 2 & 2 \\
\hline $\mathrm{HBO}$ & 3 & 3 & 3 & 6 & 6 & 5 & 5 & 3 & 4 & 6 & 6 \\
\hline wo & 2 & 3 & 3 & 5 & 5 & 4 & 4 & 3 & 4 & 5 & - \\
\hline
\end{tabular}

-: Niet beschikbaar

Opmerking: In de metingen van 2000 t/m 2002 betreft het schoolverlaters van MAVO/VBO. Vanaf de meting 2003 betreft het schoolverlaters van VMBO. 


\section{Colofon}

(C) Researchcentrum voor Onderwijs en Arbeidsmarkt (ROA). Niets uit deze uitgave mag op enige manier worden verveelvoudigd zonder voorafgaande schriftelijke toestemming van de directeur van het ROA.

\section{Researchcentrum voor Onderwijs en Arbeidsmarkt}

Maastricht University

School of Business and Economics

secretary-roa-sbe@maastrichtuniversity.nl

www.roa.nl

\section{Vormgeving}

ROA secretariaat, Maastricht

September 20II 
Researchcentrum voor Onderwijs en Arbeidsmarkt

Postbus 616

6200 MD Maastricht

$\mathrm{T}+31433883647$

$\mathrm{F}+31433884914$

secretary-roa-sbe@maastrichtuniversity.n

www.roa.nl

Maastricht University

School of Business and Economics 